\title{
Joseph Margolis' Pragmatism between Narrative and Prophecy
}

Rosa M. Calcaterra

\section{(2) OpenEdition}

1 Journals

Electronic version

URL: http://journals.openedition.org/ejpap/735

DOI: $10.4000 /$ ejpap.735

ISSN: 2036-4091

\section{Publisher}

Associazione Pragma

\section{Electronic reference}

Rosa M. Calcaterra, " Joseph Margolis' Pragmatism between Narrative and Prophecy », European Journal of Pragmatism and American Philosophy [Online], IV-2 | 2012, Online since 24 December 2012, connection on 20 April 2019. URL : http://journals.openedition.org/ejpap/735; DOI : 10.4000/ ejpap.735

This text was automatically generated on 20 April 2019.

\section{c) (ㅇ)}

Author retains copyright and grants the European Journal of Pragmatism and American Philosophy right of first publication with the work simultaneously licensed under a Creative Commons AttributionNonCommercial-NoDerivatives 4.0 International License. 


\title{
Joseph Margolis' Pragmatism between Narrative and Prophecy
}

\author{
Rosa M. Calcaterra
}

1 It is common knowledge that pragmatism acquired a new and quite relevant space within European philosophical debate during the second half of Nineteen Century, and the leading actors of such a renewed interest for the classics of American thought have been Karl Otto Apel and Jürgen Habermas. Especially in Italy, the so called revival of pragmatism took place via their neo-kantianianism, and actually one could say that the pragmatist thought has been, so to speak, cleared from previous discredit or, in the best cases, from a wide-ranging disregard just because of the persistent influence of Kantian theories on contemporary European philosophy. At the same time, the Apel-Habermas neo-kantian reevaluation of Peirce, Dewey and Mead appears striking if one considers that the most unsympathetic European receptions of pragmatism typically were, at the beginning of last century, from the neo-kantian milieu. For instance, it is worth mentioning the 1908 Third International Philosophical Conference that took place in Heidelberg, whose main subject of discussion was the pragmatist theory of knowledge or, more precisely, that one offered by William James in his book Pragmatism. In fact, this book was considered by the majority of European intellectuals as the manifesto of the entire pragmatist philosophy; neo-kantians or neo-criticists, who were predominant within German academic contest of that time, reacted to its overall approach to traditional questions with a deep disappointment. Giovanni Vailati, one of the very few Italian supporter of pragmatism at the moment, informs us that these negative reactions marked the atmosphere of the Conference and finally some supplementary sessions for discussing pragmatist epistemology were organized. ${ }^{1}$ One should add that also a number of current commentators feel quite uncomfortable in reading classical pragmatists' assertions about Kantian philosophy, including those by Peirce who, as everybody knows, declared his debts to Kant in so many occasions of his multifaceted work.

2 The importance of Kant's philosophy with regard to pragmatist European 'adventures' both negative and positive - is obviously much more complex than I have said in the very 
brief and necessary incomplete note above sketched. Anyway, Kantian paradigm surely can be considered as a pivotal, even thought non always explicit, reference point of the whole debate, old and new, on classical pragmatism and of its many-sided developments. Joseph Margolis' book Pragmatist Ascendent. A Yard of Narrative. A Touch of Profecy provides quite remarkable indications in that regard, pinpointing both the American and the European philosophical scene. More precisely, Margolis presents, in his usual intriguing style, engaging reasons for an ample historical and theoretical understanding of Kant's philosophy relevance not only within the international discussions on pragmatism but also for the making up of its own mostly distinctive features. In fact, according to him, this movement of thought mainly consists in a complex critical review of Kantian transcendentalism, a review which took up the Hegelian emphasis on the historical nature of all human expressions and achievements. The European Journal of Pragmatism and American Philosophy is particularly pleased to host a symposium on this book, which indeed represents a fascinating drawing of the deep philosophical roots of pragmatist standpoints as well as of its contemporary increasing relevance.

Joseph Margolis' philosophical work is extremely vast and ranges from ancient to modern and contemporary thought, including epistemological, aesthetical, ethical and analytic philosophy. He is without doubt a leading figure in the philosophical American scene and, at the same time, one of the most lively representative of pragmatism, analytic and European philosophy's complex interweaving. In my opinion, it is relevant considering his interest in Protagora and Aristotele, which was in the early years of his research, in fact I think that his subsequent philosophical production retains, in various outlines, some traces of ontological, epistemological and ethical problems they consigned to our cultural history. I limit myself to mentioning Protagora's issue of the epistemological relativism that, in Margolis' philosophical discourse, seems to result in his basic assertion of the constitutive function played by historical and cultural factors for the epistemic decoding of reality. Similarly, Aristotle's biology and his work's realistic constituents seem influential on his repeated efforts for concealing relativism and realism, which he has always been playing in a contrast with scientistic implications of U.S. analytic philosophy.

4 The volume to which our symposium is dedicated contains a number of polemic references to the latter current of thought that, as everybody knows, dominated the American academic scene since the 1930s, when was introduced by scholars linked to the Vienna Circle - Reichenbach, Carnap, Hempel, Tarski, Neurath and others - who were forced to leave Europe for political reasons. Richard Bernstein described this period as the beginnings of a sort of "silent revolution," which over the space of a few years led to the exclusion of pragmatism from the higher levels of philosophical debate. Margolis now underlines the turnoraund, so to speak, that has occurred both at American and European level, namely the international recovery of pragmatist perspectives and the transcription of some typical pragmatist issues in the conceptual and methodological framework of analytics, which have apparently exhausted - he maintains - their previous importance. Margolis principally reproaches the analytic philosophers for having ignored Hegel's critics to Kant, or the Hegelian opposition of historicity to Transcendentalism and, therefore, for being victims of the rigorism deriving from the Kantian apriori categories' doctrine. Just this basic deficiency resulted, according to the American philosopher, the various forms of scientism that characterized analytic thought since its outset and continues also nowadays, despite some attempts to mitigate such a trait have emerged 
within its own circle. The reputation of analytic philosophy - he writes - "still rests with its rigor, but rigor is doubtful wherever its best efforts are too slow to admit the failure of its reductionisms, supervenientisms, eliminativisms, axiomatizations, systems of causal closure or the rest of the its utopian projects" (111).

The criticism of the analytics' lack of understanding Hegel's contribution to the overcoming of Kantian transcendentalism mirrors perfectly Margolis' conception of philosophy as well as his pragmatism's 'narrative' and 'prophecy.' To be sure, the Hegelian emphasis on the historical dimension is a liet motiv of his several books concerning pragmatist philosophy and its specific position within contemporary philosophy, particularly: Pragmatism without Foundations: Reconciling Relativism and Realism, Reinventing Pragmatism. American Philosophy at the End of the Twentieth Century, and Pragmatism Advantages: American and European Philosophy at the End of Twentieth Century. As regards to the conception of philosophy, there is a tight connection between Hegelian concept of Bildung and Margolis constructivist perspective on scientific and philosophical inquiries, a connection whose theoretical nucleus appears in his assertion that the most essential Hegel's legacy is the demonstration that "contingencies of the historical or geistlich variety" prop up philosophy as "an interpretive discipline that never pretends to grasp (or need) the impossible rigors of Kantian transcendental necessity or a realist reading of 'absolute Idealism' at its absolute limit" (43). This is probably a questionable reading of Hegelian idea of philosophy but, as a matter of fact, such assertion summarizes Margolis' open option in favor of Hegel's historicism, and this properly means defending an overall anti-dogmatic perspective, according to which there aren't sharp boundaries neither between philosophical and scientific enquiries and acquirements nor between the objective and the subjective sides of knowing and reasoning. It is an option that evidently implies the rejection of any kind of apriorism and, accordingly, the refusal of the Kantian quest for definitive necessity and universality of our 'rational' assertions. However, all that does not mean embracing skepticism. Otherwise, what is firmly maintained is the inevitable interference of the cultural and the natural dimensions involved in both the knowing and the known, so that all rational-logical-scientific practices must be considered as constructive processes of truth and objectivity that are always corrigible and improvable.

It is not difficult noticing the correspondence of Margolis' constructivist perspective with one of the most documented features of pragmatist philosophy in general. In fact, he himself assigns the distinctive mark of contemporary and future pragmatism to a more and more aware and attentive constructivism, and this particularly means inviting to get free from the anxiety of ahistorical principles and tools for knowing and acting. It is worth repeating once again that what here is at stake is the Kant-Hegel controversy, and the net conviction of the American philosopher that Hegel corrected transcendentalism introducing an irreversible way of thinking - "the conceptual novelty of a historied and encultured world" -, which has been confirmed by most of philosophical and epistemological trends developed in late twentieth-century. Of course, Margolis does not undervalue Kant's great contribution to the growth of Eurocentric philosophy. In fact he considers Hegel's philosophy as a "continuation of the Kantian project," asserting that any further progress of philosophical researches cannot but draw the Kantian-Hegelian line, which marks all contemporary philosophy even thought in so many different ways. Thus, Ernest Cassirer - to whom Margolis dedicated his interesting 2010 essay Toward a Theory of Human History - is more than once quoted as representative of a "Hegelianized 
Kantianism" that, in his opinion, also characterizes Peirce's philosophy, especially as far as the founder of pragmatism depicts scientific research as an intersubjective activity that is inevitably effected by historical circumstances and constrains. One could expect a more detailed comparison between these two thinkers, both so much engaged in theoretical reflection on the logic-symbolic level of human performances, but anyway there is a very attractive suggestion for a possible combination of their own analysis, provided the differences - as Margolis underlines - in their reception of Darwinism.

7 The philosophical importance of Darwinian biological evolutionism is one of the keysubjects of the book: it makes up Margolis' constructionism, his reading of Peirce's most important questions and, eventually, his 'prophecy' for the advancement of pragmatism. In a nutshell, his basic thesis is that what present and future philosophy needs is to enhance pragmatist essential achievements "by conjoining the essential lessons of Hegel and what, independently, has been made of Charles Darwin's and post-Darwinian inquiries" (54). In other words, the future of the whole of Eurocentric philosophy calls for 'Darwinizing Hegel' and 'Hegelianizing Darwin,' as - according to Margolis - classical pragmatists more or less explicitly actually did, although without a full understanding of the implications of such a philosophical strategy (119-20). This is a task still open but it is essential considering that classical pragmatism was a continuation of Hegel's corrections of Kantian transcendentalism along a naturalistic line. The improvement of pragmatism implies just a development of such very special naturalistic line, taking advantage from the post-darwinian paleoanthropology so that constructivism would result the only inevitable solution to the problem of knowledge.

In a quite complex passage of the book, Margolis describes what he means by 'constructivism':

I use the terms 'constructed,' 'constructive,' 'constructivist' in two quite different but hardly unrelated senses: in one, 'constructive' means 'artifactual' (or 'hybrid') in the specific sense in which the self and all things cultural are artifactual transforms of the biological or material; in the other, 'constructivist' means 'conceptually inseparable' - in the sense in which the contribution of the subjective and objective "parts" of cognitive states cannot be separately assessed. The first draws attention to the cultural dimensions of all forms of inquiry and human intelligence; the second, the impossibility of outflanking the contingency of cognitive claims. Together, the two senses account for the 'constructivist' nature of the realism of science (and metaphysics) - consistent with preserving the distinction between metaphysical and epistemological questions. (38-9)

9 I think this passage can be considered as a significant summary of the overall Margolis' theoretical contribution to contemporary philosophy, a contribution which, in my opinion, is perfectly in line with the non reductionist form of naturalism that is claimed by classical as well as by the majority of today's pragmatists.

of course, the attribution of a naturalism of some kind to Peirce - as Margolis invites - is quite open to discussion, in fact a lot of critical studies insist definitely on peircean antinaturalist assertions. As far as I am concerned, Margolis' interpretative line is more than justified, provided my conviction that any interpretation of great philosophical works cannot but favouring some particular aspect, and this is especially relevant in relation to Peirce's non systematic and typically many-sided work. Indeed, in agreement with Gadamer, I am convinced that the readings of works of the past could be all the more fruitful the more they are nourished by the need to find possible answers to current question, and this seems to me Margolis' constant attitude towards the writings of the 
classical pragmatists as well as of Kant, Hegel and other great figures of Western philosophical history. I consider this aspect as a salient and very positive feature of his intense research activity, which this book establishes as promising of new, meaningful suggestions, mainly with regard to a more and more fertile relationship of philosophy with human and natural sciences that should generate a theory of the self actually coherent with the non reductionist naturalism he theorizes.

Let me conclude my remarks by pointing out Margolis' effort to demonstrate the centrality of fallibilism within Peirce's thought, and above all his indication of the essential strength of peircian concept of 'infinite hope' for reconciling realism and idealism. However, I do not find important to demonstrate that fallibilism is, so to speak, the 'very essence' of Peirce's philosophy, as Margolis apparently claims along his debate with Nathan Hauser. The search for a philosopher's unique, definitive conceptual devise or purpose seems to me in contrast not only with his interpretative style of philosophical works, as above mentioned, but also with the following paradigmatic peircian assertion

Philosophy ought [...] trust rather to the multitude and variety of its arguments than to the conclusiveness of any one. Its reasoning should not form a chain which is no stronger than its weakest link, but a cable whose fibres may be ever so slender, provided they are sufficiently numerous and intimately connected. ${ }^{2}$

Thus, I wonder whether it would not be useful to turn to James, who is mostly neglected in this book, reflecting in particular on Jamesian perspectivism and pluralist metaphysics in order to corroborate the theoretical framework advocated by Margolis. Indeed, in my opinion, one can find on both sides motives quite compatible with the perspectives of the book here at issue: above all, on the one hand, one could appeal to the realist instance that pervades James' perspectivism and, more generally, to his own effort to combine realism and idealism; on the other hand, one could find a specific reference point for a non reductionist naturalism in the concept of 'possibility' supporting Jamesian metaphysics, which indeed gets rid of the concept of 'essence' so central in Western traditional metaphysics. Most probably, especially Margolis' crucial conception of the self as 'natural artifact' could take advantage from Jamesian philosophical translation of Darwin's biological evolutionism, considering also the deep ethical implications assigned to the category of possibility by the author of The Principles of Psychology.

\section{BIBLIOGRAPHY}

FERRARI M., (2010a), "Heidelberg 1908. Giovanni Valilati, Wilhelm Jerusalem e il pragmatismo Americano," Giornale critico della filosofia italiana 1.

FERRARI M., (2010b), “William James a Vienna,” in R. M. Calcaterra \& G. Maddalena (eds.), Itinerari pragmatisti, Paradigmi, no. 3.

PEIRCE Ch. S. (1992), Some Consequences of Four Incapacities, in The Essential Peirce, N. Houser and C. Kloesel (eds.), vol. 1, Bloomington and Indianapolis, Indiana University Press. 


\section{NOTES}

1. For an account of early German and Austrian reception of pragmatism, see M. Ferrari 2010a, and $2010 \mathrm{~b}$.

2. Peirce (1992: 29).

\section{AUTHOR}

ROSA M. CALCATERRA

Università Roma Tre

calcater[at]uniroma3.it 